\title{
Sortase inhibitor phenyl vinyl sulfone inhibits Renibacterium salmoninarum adherence and invasion of host cells
}

\author{
Ponnerassery S. Sudheesh ${ }^{1,2}$, Samuel Crane ${ }^{1,3}$, Kenneth D. Cain ${ }^{2}$, Mark S. Strom ${ }^{1, *}$ \\ ${ }^{1}$ Northwest Fisheries Science Center, NOAA Fisheries Service, 2725 Montlake Boulevard East, Seattle, \\ Washington 98112, USA \\ ${ }^{2}$ Department of Fish and Wildlife Resources and The Aquaculture Research Institute, University of Idaho, \\ Moscow, Idaho 83844, USA
}

${ }^{3}$ Present address: Graduate Center, The City University of New York and the Sackler Institute for Comparative Genomics, American Museum of Natural History, Central Park West at 79th Street, New York, New York 10024, USA

\begin{abstract}
Renibacterium salmoninarum, the causative agent of bacterial kidney disease in salmonid fishes, is a Gram-positive diplococcobacillus belonging to the family Micrococcaceae. Analysis of the genome sequence of the bacterium demonstrated the presence of a sortase homolog (srtD), a gene specifying an enzyme found in Gram-positive bacteria and required for covalent anchoring of cell surface proteins. Interference of sortase activity is being examined as a target for therapeutic prevention of infection by several pathogenic Gram-positive bacterial species. In silico analysis identified 8 open reading frames containing sortase recognition motifs, suggesting these proteins are translocated to the bacterial cell wall. The sortase and potential sortase substrate genes are transcribed in $R$. salmoninarum, suggesting they encode functional proteins. Treatment of $R$. salmoninarum with phenyl vinyl sulfone (PVS) significantly reduced bacterial adherence to Chinook salmon fibronectin. In addition, the ability of the PVS-treated bacteria to adhere to Chinook salmon embryo cells (CHSE-214) in vitro was dramatically reduced compared to that of untreated bacteria. More importantly, PVS-treated bacteria were unable to invade and replicate within CHSE-214 cells (demonstrated by an intracellular growth assay and by light microscopy). When treated with PVS, $R$. salmoninarum was not cytopathic to CHSE-214 cells, whereas untreated bacteria produced cytopathology within a few days. These findings clearly show that PVS, a small molecule drug and a known sortase inhibitor, can interfere with the ability of $R$. salmoninarum to adhere and colonize fish cells, with a corresponding decrease in virulence.
\end{abstract}

KEY WORDS: Renibacterium salmoninarum • Bacterial kidney disease · Anti-virulence chemotherapy • Adherence $\cdot$ Invasion $\cdot$ Host cell sortase inhibitor $\cdot$ Phenyl vinyl sulfone

\section{INTRODUCTION}

Adherence to host tissues is an essential requirement for many bacterial pathogens to establish infections in specific hosts and cause disease. Gram-positive bacteria achieve this in part by employing an array of surface-displayed protein virulence factors called
MSCRAMs (microbial surface components recognizing adhesive matrix molecules) (Patti et al. 1994). These surface-displayed proteins mediate initiation and propagation of infection through adherence to host endothelial tissue and immune system evasion (Schneewind et al. 1995) often determining both bacterial host range and site of infection (Foster \& McDevitt 
1994, Kehoe 1994). MSCRAMs have specific C-terminal anchoring signals or cell wall sorting (CWS)-motifs that are recognized by a membrane transpeptidase called sortase. Sortase catalyzes covalent anchoring of these proteins to the peptidoglycan surface during cell wall synthesis (reviewed in Navarre \& Schneewind 1999, Ton-That et al. 2004, Marraffini et al. 2006). Elimination of sortase activity and the consequent disruption of surface protein anchoring correlates with a dramatic decrease in pathogenicity of Gram-positive bacteria in animal infections (Mazmanian et al. 2000, Bolken et al. 2001, Bierne et al. 2002, Garandeau et al. 2002, Jonsson et al. 2002, Weiss et al. 2004). Sortase is also involved in the assembly of cell surface pili on Gram-positive bacteria, which often aid attachment to host cells (Ton-That \& Schneewind 2003). Collectively, these and other findings suggest that sortases are promising targets for new antibacterial drugs (Schneewind et al. 1993, Frankel et al. 2004, Ton-That et al. 2004, Weiss et al. 2004, Zink \& Burns 2005). However, there have been few studies focused on the development of specific inhibitors of sortases for the treatment of Gram-positive bacterial infections.

Vinyl sulfones are a group of small molecule electrophilic inactivators of cysteine proteinases (Hanzlik \& Thompson 1984) that inhibit sortase enzyme activity. Significant attenuation of virulence with vinyl sulfones has been demonstrated for Gram-positive bacteria (Frankel et al. 2004) with no effects on viability, thus avoiding selective pressure to develop resistance (Aberg \& Almqvist 2007). Since there is development of resistance against almost any antibiotic available for treatment today, such an anti-infective strategy may prove valuable in the treatment of bacterial infections. Moreover, because vinyl sulfones are small molecule drugs, they may have the added advantage of easy absorption into host tissues.

Renibacterium salmoninarum is a Gram-positive, slow growing bacterium and the causative agent of bacterial kidney disease (BKD), a chronic granulomatous infection in wild and cultured salmonid fish (Fryer \& Sanders 1981). A common practice for managing the disease in fish supplementation and conservation hatcheries is prophylactic use of a macrolide drug, erythromycin under a FDA-investigational new animal drug (INAD) approval system (FDA = US Food and Drug Adminstration). However, erythromycin treatment does not completely eliminate the pathogen, and in fact the bacterium and clinical signs of BKD reemerge soon after treatment is stopped (Wolf \& Dunbar 1959). Persistence of the bacterium in the host has been attributed to its ability to survive intraovum (Bruno \& Munro 1986, Evelyn et al. 1984) or intracellularly (Bandín et al. 1993, Gutenberger et al. 1997, McIntosh et al. 1997, Young \& Chapman 1978). Intra- cellular survival allows the bacteria to escape both humoral and cellular immune responses as well as the action of antibiotics that normally act in the extracellular milieu (Fryer \& Lannan 1993). In order to improve treatment efficacy, azithromycin (another macrolide drug with better tissue permeability and persistence) is being used to treat BKD in valuable endangered salmon stocks reared in captivity (Fairgrieve et al. 2005, 2006). However, development of resistance to antibiotics is an increasingly important concern, not only for human health implications, but also in aquatic organisms (WHO 1997, Cabello 2006). Recent evidence also indicates that long-term prophylactic use of erythromycin can produce toxicity and cause a reduction in reproductive success in Chinook salmon (Fairgrieve et al. 2006). Clearly there is a strong need for alternative, non-antibiotic based drugs for treating BKD.

Genome sequencing of Renibacterium salmoninarum was recently completed and offers tremendous opportunities for identifying novel vaccine and drug targets. Until annotation of the genome, the presence of sortase and sortase-mediated translocation of proteins to the cell surface were unknown in this organism. We present a characterization of the $R$. salmoninarum sortase and sortase substrate genes, and the inhibitory effect of a known sortase inhibitor, phenyl vinyl sulfone (PVS), on the adherence, invasion and replication of the bacteria in a Chinook salmon embryo cell line. In addition, we investigated the effect of PVS on the expression and localization of cell-wall bound proteins in $R$. salmoninarum.

\section{MATERIALS AND METHODS}

Bacteria and culture conditions. Renibacterium salmoninarum ATCC 33209 (Rs-33209, American Type Culture Collection), which was originally isolated from a Chinook salmon in Oregon (Sanders \& Fryer 1980) was used in this study. Bacteria were grown at $15^{\circ} \mathrm{C}$ with constant stirring in selective kidney disease medium (SKDM-2) broth (Evelyn 1977) containing $0.05 \%(\mathrm{w} / \mathrm{v})$ cysteine- $\mathrm{HCl}$ and $10 \%(\mathrm{v} / \mathrm{v})$ fetal bovine serum. Glycerol stocks of the bacteria were prepared in SKDM-2 medium containing $15 \%$ glycerol, and were kept at $-80^{\circ} \mathrm{C}$ for long-term storage.

Bioinformatic analysis and database searches. In silico discovery of putative sortase enzymes was conducted by scanning all open reading frames (ORFs) in the Rs-33209 genome with a published sortase profile hidden Markov model (HMM) of 6 sortase subfamilies (Comfort \& Clubb 2004) using the program HMMER, version 2.3 (Eddy 1998). To further verify subfamilial assignment, potential sortase proteins were aligned to 
a published set of sortase enzymes (Dramsi et al. 2005). A neighbor-joining tree was built from 54 aligned sortase amino acid sequences (bootstrapped 100 times) using the program MAFFT (Katoh et al. 2005).

After sortase gene discovery, sortase substrate proteins were identified using a modified version of the substrate search of Boekhorst et al. (2005). Amino acid sequences were scanned for one tripartite pattern and one cleavage motif using ScanProsite (de Castro et al. 2006). The cleavage motif used L-[PA]-X-[TA]-[GNSD] is the most relaxed query (more matches at the cost of more false positives) and is based on the subfamily 5 sorting signal. The tripartite pattern L-A-X-[TA][GNSD]-X(1,11)-[VIFAGTSMLWCNRK] $(14,20)$-X(6)$[R K](1,5)$ incorporates the cleavage motif, the transmembrane region and the anchor site typical of sortase substrates. Matches to either pattern were retained and HMMER was used to build a HMM. The entire Rs-33209 genome was scanned for matches using this HMM.

Sequences containing the query cell wall sorting signal (cleavage or tripartite) were considered true putative sortase substrates if they had 3 properties: (1) they contained a transmembrane region in the $\mathrm{C}$-terminus, (2) they had no more than 3 transmembrane helices and (3) they showed no homology to known intracellular proteins (Boekhorst et al. 2005). Transmembrane regions were predicted by the program TMHMM, version 2.0 (Krogh et al. 2001, Sonnhammer et al. 1998). The genome was also analyzed using the MEME/ MAST software, as outlined by Boekhorst et al. (2005)

PCR and RT-PCR analysis. The gene sequences specifying sortase and sortase substrate proteins were PCR amplified from genomic DNA of Rs-33209. Transcription of sortase and sortase substrates was assessed by reverse transcription (RT)-PCR. The primer pair used for the sortase gene were 5'-AGCAATTCTAGCGGCAAAAC-3' and 5'-GTTCGGAAGATCCAACCGTA-3' and the primer pairs used for sortase substrates are listed in Table 1. Total DNA and RNA were extracted from Rs-33209 cells by DNeasy genomic DNA extraction kit (Qiagen) and Ribopure bacterial RNA extraction kit (Ambion), respectively, according to the manufacturers' instructions. Purified RNA was treated with DNase I $\left(0.16 \mathrm{U} \mathrm{\mu l}^{-1}\right)$ at $37^{\circ} \mathrm{C}$ for $30 \mathrm{~min}$ to remove any residual DNA. First-strand cDNA synthesis was done using the Superscript ${ }^{\mathrm{TM}}$ III first-strand synthesis system for RT-PCR (Invitrogen). After the first strand synthesis, the cDNA was treated with

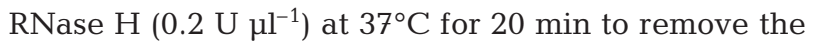
RNA template from the cDNA:RNA hybrid. PCR and the second step of RT-PCR reactions were carried out in $50 \mu \mathrm{l}$ reaction volumes containing $50 \mathrm{ng}$ genomic DNA for PCR or $0.3 \mu \mathrm{g}$ of cDNA as template DNA for RT-PCR, $200 \mu \mathrm{M}$ concentration of each dNTP, $30 \mathrm{pM}$ of each primer, $1.5 \mathrm{mM} \mathrm{MgCl}_{2}$ and $2.5 \mathrm{U}$ of Taq DNA polymerase (Promega) in $1 \times$ Taq reaction buffer. PCR cycling conditions consisted of an initial denaturation at $95^{\circ} \mathrm{C}$ for $1 \mathrm{~min}$ followed by 30 cycles of denaturation at $95^{\circ} \mathrm{C}$ for $30 \mathrm{~s}$, primer annealing at $48^{\circ} \mathrm{C}$ for $20 \mathrm{~s}$, and primer extension at $72^{\circ} \mathrm{C}$ for $1 \mathrm{~min}$. This was followed by a final extension at $72^{\circ} \mathrm{C}$ for $2 \mathrm{~min}$. The size and quality of PCR products were determined by electrophoresis on $1.5 \%$ agarose gel at a constant current of $100 \mathrm{~V}$ and visualized under UV transillumination. One kb and 100 bp DNA ladder (New England Biolab) were used as the standard for size comparison.

Growth of bacteria in SKDM-2 medium containing vinyl sulfones. Six vinyl sulfone drugs, viz. phenyl vinyl sulfone (PVS), methyl vinyl sulfone, ethyl vinyl

Table 1. Renibacterium salmoninarum-33209: probable SrtD substrates

\begin{tabular}{|c|c|c|c|}
\hline $\begin{array}{l}\text { ORF ID } \\
\text { (Accession no.) }\end{array}$ & Primer pairs used in PCR and RT-PCR & Function/Annotation & CWS- motif \\
\hline $\begin{array}{l}\text { RRSA00417 } \\
(\text { EF426712) }\end{array}$ & $\begin{array}{l}\text { 5'-CCTTGTCGGCCTTGTCTTAG-3' } \\
\text { 5'-GACGACGTCGAACGGTCAG-3' }\end{array}$ & $\begin{array}{l}\text { Possible proteinase } \\
\text { (Rhodococcus sp. RHA1) }\end{array}$ & LAnTG \\
\hline RRSA00636 & 5'-AAGCGCCAGTCAAGAACG-3' & Putative glycosyl hydrolases family 31 & \\
\hline (EF426714) & 5'-ACGACGAAGCAGCAGTAAGC-3' & (Arthrobacter aurescens TC1) & LAaTG \\
\hline $\begin{array}{l}\text { RRSA01045 } \\
\text { (EF426715) }\end{array}$ & $\begin{array}{l}\text { 5'-GCCAAGATGGCAGCGTTT-3' } \\
\text { 5'-CGAGCGACCACCGTCATAC-3' }\end{array}$ & $\begin{array}{l}\text { Hypothetical membrane protein } \\
\text { (Bifidobacterium longum NCC2705) }\end{array}$ & LAaTG \\
\hline $\begin{array}{l}\text { RRSA01248 } \\
\text { (EF426716) }\end{array}$ & $\begin{array}{l}\text { 5'-GATATGAAATCCCTCTTTTACCG-3' } \\
5^{\prime} \text {-CCGAGCGAAGAAAACTGATG-3' }\end{array}$ & $\begin{array}{l}\text { Putative partial cell-surface adhesin, Cna B-type } \\
\text { (Chloroflexus aggregans DSM 9485) }\end{array}$ & LAnTG \\
\hline $\begin{array}{l}\text { RRSA01787 } \\
\text { (EF426717) }\end{array}$ & $\begin{array}{l}\text { 5'-ACCAATTCGTGCAGAAAACC-3' } \\
\text { 5'-TAGTTGAAGCGTTTGCGTTG-3' }\end{array}$ & $\begin{array}{l}\text { Acid phosphatase (EC 3.1.3.2) } \\
\text { (Corynebacterium jeikeium K411) }\end{array}$ & LAaTG \\
\hline $\begin{array}{l}\text { RRSA02499 } \\
\text { (EF426718) }\end{array}$ & $\begin{array}{l}\text { 5'-TTGGTGGACATCGCGAAC-3' } \\
\text { 5'-GAGTGACGGTGCCTTCGTA-3' }\end{array}$ & $\begin{array}{l}\text { Hypothetical protein AAur_1465 } \\
\text { (Arthrobacter aurescens TC1) }\end{array}$ & LAeTG \\
\hline $\begin{array}{l}\text { RRSA00949 } \\
\text { (EF426719) }\end{array}$ & $\begin{array}{l}\text { 5'-CGGGGACGACCAAAACTT-3' } \\
\text { 5'-TAAATTTACCGGGTAGCGATAAG-3' }\end{array}$ & $\begin{array}{l}\text { Hypothetical protein Arth_2238 } \\
\text { (Arthrobacter sp. FB24) }\end{array}$ & LPvAG \\
\hline $\begin{array}{l}\text { RRSA02971 } \\
\text { (EF426720) }\end{array}$ & $\begin{array}{l}\text { 5'-GAAAATCGCTGGAACTGTTG-3' } \\
\text { 5'-AGAGCCGCCCTGGCTTAC-3' }\end{array}$ & $\begin{array}{l}\text { Putative integral membrane protein } \\
\text { (Arthrobacter aurescens TC1) }\end{array}$ & LAiTG \\
\hline
\end{tabular}


sulfone, divinyl sulfone, phenylsulfonyl ethylene and phenyl trans-styryl sulfone (all from Sigma-Aldrich) were screened for their effect on cell growth and viability. One molar stock solutions of all drugs were prepared in $100 \%$ sterile dimethyl sulfoxide (DMSO) (Research Organics). Bacteria were grown for $14 \mathrm{~d}$ at $15^{\circ} \mathrm{C}$ with constant stirring in SKDM-2 broth containing different concentrations ( 0.625 to $10 \mathrm{mM}$ ) of the vinyl sulfone drugs. As a control, sterile DMSO alone was added to bacterial cultures not treated with drugs. In order to assess the effect of PVS on bacterial growth, $14 \mathrm{~d}$ old $10 \mathrm{ml}$ broth cultures were used to inoculate $100 \mathrm{ml}$ SKDM-2 medium with and without PVS. Aliquots of cultures were drawn on alternate days for $14 \mathrm{~d}$ and optical density $\left(\mathrm{OD}_{525}\right)$ was measured to assess the growth.

Purification of Chinook salmon fibronectin. Fibronectin protein from the muscle tissue of healthy Chinook salmon was purified by affinity chromatography. Muscle tissue was aseptically removed from Chinook salmon and homogenized in binding buffer (PBS, pH $7.2)$ using a sterile tissue homogenizer. One milliliter of the macerated tissue extract ( $\sim \mathrm{mg}$ ) was applied to a $10 \mathrm{ml}$ gelatin sepharose ${ }^{\mathrm{TM}}$ 4B column (Amersham Pharmacia Biotech) that had been previously equilibrated with binding buffer. Following 2 washes with binding buffer, the bound fibronectin was eluted with binding buffer containing $8 \mathrm{M}$ urea. Eluted proteins were dialyzed for $24 \mathrm{~h}$ against PBS ( $\mathrm{pH} 7.2$ ), concentrated, and stored at $-20^{\circ} \mathrm{C}$ until used. The purity of the protein was ascertained by SDS-polyacrylamide gel electrophoresis. The protein concentration was determined using a NanoDrop ND-1000 spectrophotometer (NanoDrop Technologies).

Chinook salmon fibronectin binding assays. The ability of bacteria to bind Chinook salmon fibronectin was assayed using a fibronectin-enzyme linked immunosorbent assay (ELISA). Bacteria grown in SKDM2 medium in the presence of each of 6 different vinyl sulfone drugs were screened for their ability to bind Chinook salmon fibronectin and compared to the fibronectin binding ability of normal untreated bacteria. Wells of 96 well flat-bottom microtitre ELISA plates were coated with $100 \mu \mathrm{l}$ of Chinook salmon fibronectin $\left(10 \mu \mathrm{g} \mathrm{ml}^{-1}\right)$ in $0.1 \mathrm{mM}$ carbonate buffer ( $\mathrm{pH}$ 9.6). The plates were covered and incubated overnight at $4^{\circ} \mathrm{C}$. After rinsing 4 times with PBS containing 0.75\% Tween-20 (PBS-T), the wells were blocked with $100 \mu \mathrm{l}$ of $3 \%$ BSA (bovine serum albumin) in PBS for 1 to $2 \mathrm{~h}$ at $37^{\circ} \mathrm{C}$ and then rinsed once with PBS-T.

Bacteria were grown at $15^{\circ} \mathrm{C}$ in SKDM-2 broth medium containing different concentrations of vinyl sulfone drug ranging from 0.625 to $10 \mathrm{mM}$ or without the drug for $14 \mathrm{~d}$. Bacteria were then harvested by centrifugation at $5000 \times g$ for $10 \mathrm{~min}$, washed once with
PBS and resuspended in PBS-T containing 1\% BSA. The bacterial samples were adjusted to an $\mathrm{OD}_{525}$ of 0.5 , and $100 \mu \mathrm{l}$ of each suspension was added to a fibronectin-coated well and incubated at $37^{\circ} \mathrm{C}$ for $2 \mathrm{~h}$. After washing the wells 4 times with wash buffer (Kirkegaard \& Perry Laboratories) $200 \mu \mathrm{l}$ of peroxidase conjugated goat anti-Renibacterium salmoninarum polyclonal antibody (Kirkegaard \& Perry Laboratories) diluted 1:4000 in 1× milk was added and incubated at room temperature for $2 \mathrm{~h}$. After 4 washes with wash buffer, $200 \mu \mathrm{l}$ of 2,2'-azino-bis (3-ethyl-benzthiazoline6 -sulphonic acid) (ABTS) peroxidase substrate (Kirkegaard \& Perry Laboratories) were added and incubated at $37^{\circ} \mathrm{C}$ for $30 \mathrm{~min}$. The $\mathrm{OD}_{405}$ of each reaction was measured using an ultra microplate reader (EL ${ }_{\mathrm{X}} 808_{\mathrm{IU}}$, BioTek Instruments). Triplicate samples were used for each treatment and the assays were repeated at least 3 times.

Cell adherence assays. The ability of Renibacterium salmoninarum to adhere to host cells was measured in 2 different ways. Initially, adherence of Rs-33209 to CHSE-214 cells was visualized by a fluorescent antibody staining procedure. Bacteria were grown in SKDM-2 medium with and without $10 \mathrm{mM}$ PVS, as described previously. The bacteria were harvested by centrifugation at $5000 \times g$ for $10 \mathrm{~min}$, washed once with HBSS, and resuspended in MEM complete medium, and the optical density $\left(\mathrm{OD}_{525}\right)$ was adjusted to 0.5 . CHSE-214 cells were cultured on cell culture-treated Thermanox sterile coverslips (Nalge Nunc) kept in 24 -well culture plates and incubated at $15^{\circ} \mathrm{C}$ for 24 to $48 \mathrm{~h}$. The cell monolayers on the coverslips were washed once with HBSS, infected with $100 \mu$ l of the bacterial suspension per well and incubated at $15^{\circ} \mathrm{C}$ for $2 \mathrm{~h}$. The monolayer was washed 4 times in PBS and once in PBS containing $0.1 \%$ triton X-100. The washed monolayer was then covered with $30 \mu \mathrm{l}$ of fluoresceinconjugated affinity purified anti- $R$. salmoninarum goat antibody (50 $\mu \mathrm{g} \mathrm{ml}^{-1}$ in PBS, $\mathrm{pH}$ 7.2) and incubated for $1 \mathrm{~h}$ at room temperature. After reacting with antibody the monolayers were washed once with PBS and counterstained with $0.02 \%$ Evan's blue stain for $5 \mathrm{~min}$. The stained monolayers were rinsed with PBS and airdried. Epifluorescence microscopy was performed on a light microscope (Carl Zeiss, Axioscope) using the $100 \times$ objective and appropriate filters, and imaged using a Qimaging Micropublisher 3.3 RTV camera and software system.

For a quantitative measure of Renibacterium salmoninarum adherence, CHSE-214 cells were grown in MEM-complete medium containing 10\% fetal bovine serum at $15^{\circ} \mathrm{C}$. The cells were counted using a Neubauer hemocytometer, seeded at a density of $0.5 \times$ $10^{5}$ cells well $^{-1}$ in 24 -well tissue culture plates, and incubated at $15^{\circ} \mathrm{C}$ for 24 to $48 \mathrm{~h}$ to confluent monolay- 
ers. Bacteria were grown in SKDM-2 tubes for $14 \mathrm{~d}$ at $15^{\circ} \mathrm{C}$, washed once with PBS and resuspended in MEM-complete medium. For the cell adherence assay, CHSE-214 cells were infected with bacteria at a multiplicity of infection (m.o.i.) of 10 bacteria per fish cell for $2 \mathrm{~h}$ at $15^{\circ} \mathrm{C}$. The monolayer was then washed 5 times with Hank's balanced salt solution (HBSS). The washed cells were disrupted by the addition of $0.5 \mathrm{ml}$ sterile deionized ice-cold water and repeated pipetting. Serial dilutions of the lysate were plated onto SKDM-2 agar for counts of viable bacteria. The percent adherence was calculated as follows:

\section{(CFU on plate/CFU in original inoculum) $\times 100$}

where CFU = colony forming units. Assays were performed in duplicate and repeated at least 3 times.

Intracellular growth determination. For intracellular growth assay, CHSE-214 cells were infected with bacteria at an m.o.i. of 10 bacteria per fish cell and incubated for $8 \mathrm{~h}$ at $15^{\circ} \mathrm{C}$. Monolayers were washed 5 times with HBSS, followed by the addition of MEM complete medium containing $10 \mu \mathrm{g} \mathrm{ml}^{-1}$ gentamycin and incubation at $15^{\circ} \mathrm{C}$ for an additional $30 \mathrm{~min}$. Monolayers were then washed 3 times with HBSS, fresh MEM complete medium without gentamycin was added and incubated at $15^{\circ} \mathrm{C}$. After incubating the plates for different time points, the monolayer was washed again with HBSS and lysed with sterile deionized ice-cold water and repeated pipetting. The cell monolayers were observed microscopically to assure complete lysis. Serial dilutions of the lysate were plated onto SKDM-2 agar for counts of viable bacteria. The time immediately following the removal of the gentamycin was taken as the zero time point. Assays were performed in triplicate and repeated at least 3 times.

For Giemsa staining, the monolayers were grown on cell culture-treated Thermanox sterile coverslips (Nalge Nunc) kept in 24-well culture plates, and infection was performed as described in the intracellular growth assay. The coverslips were removed from the wells at different time points after the gentamycin treatment and incubation, and stained with $0.01 \%$ Giemsa stain for $45 \mathrm{~min}$. The stained monolayers on the coverslips were observed under a light microscope (Carl Zeiss, Axioscope) using a 100× objective, and representative cells from at least 3 repeated experiments were photographed using a Qimaging Micropublisher 3.3 RTV camera and software system.

Cytopathic effect (CPE) of Renibacterium salmoninarum. The CPE assay was performed by preparing CHSE-214 cell monolayers and bacteria as described above. CHSE-214 cells were infected at an m.o.i. of 10 bacteria per fish cell and observed for CPE for up to 2 wk. Typical CPE of $R$. salmoninarum on CHSE-214 cells included morphological changes such as formation of rounded cells and cell detachment as the infection progressed. Representative monolayers from at least 3 repeated experiments were photographed using a Nikon digital camera mounted on an inverted microscope (Carl Zeiss, Axiovert 135). Toxicity of PVS to CHSE-214 cells was assayed by growing the cell monolayers in 24-well tissue culture plates for 24 to $48 \mathrm{~h}$ and then exposing them to different doses of PVS ranging from $0.001 \mathrm{mM}$ to $100 \mathrm{mM}$. The monolayers were incubated at $15^{\circ} \mathrm{C}$ and observed daily for visible $\mathrm{CPE}$ and morphological changes for $14 \mathrm{~d}$.

Isolation of cell wall-bound proteins. Bacteria were grown at $15^{\circ} \mathrm{C}$ for $14 \mathrm{~d}$ in SKDM-2 broth medium with or without $10 \mathrm{mM}$ PVS. Bacteria were harvested by centrifugation at $5000 \times g$ for $10 \mathrm{~min}$. Cell wall-bound proteins of Renibacterium salmoninarum were prepared using modified methodology of StalhammarCarlemalm et al. (1993). Briefly, the bacteria were washed twice with Tris-HCl buffer (50 mM, pH 7.3) and resuspended in osmotic digestion buffer $(20 \%$ sucrose-2.5 $\mu \mathrm{M}$ phenylmethylsulfonyl fluoride in $50 \mathrm{mM}$ Tris-HCl, pH 7.3). Cell wall-bound proteins were enzymatically released from the bacterial cells by adding mutanolysin (Sigma-Aldrich) in potassium phosphate buffer (10 mM, pH 6.2) to a final concentration of $350 \mathrm{U} \mathrm{ml}^{-1}$. The digestion reaction was incubated for $18 \mathrm{~h}$ at $37^{\circ} \mathrm{C}$ with gentle shaking followed by 2 centrifugations at $20000 \times g$ for $15 \min \left(4^{\circ} \mathrm{C}\right)$ in a tabletop centrifuge (Eppendorf, 5417R) in order to remove cell debris and remaining protoplasts. The supernatant containing the proteins released from the cell wall was frozen at $-20^{\circ} \mathrm{C}$ for subsequent 2 -dimensional electrophoresis (2-DE). The protein concentration was determined using a NanoDrop ND-1000 spectrophotometer (NanoDrop Technologies).

Two dimensional polyacrylamide gel electrophoresis analysis. The cell wall-bound protein samples were extracted in a sample extraction buffer containing $5 \mathrm{M}$ urea, $2 \mathrm{M}$ thiourea, $2 \mathrm{mM}$ tributyl phosphene (TBP), $2 \%$ CHAPS, $2 \%$ sulfobetaine 3-10, 0.5\% biolyte ampholyte, $10 \mathrm{mM}$ Tris and $0.001 \%$ Orange G dye. Extracted protein samples were applied to $7 \mathrm{~cm}$ IPG strips ( $\mathrm{pH} 4-7$ ) (Bio-Rad) (25 $\mu \mathrm{g}$ total protein strip $^{-1}$ ) and rehydrated overnight in a humidified chamber at room temperature. First dimension isoelectric focusing was performed on IPG strips using a Mini Protean IEF cell (Bio-Rad). The strips were focused initially for $15 \mathrm{~min}$ at $250 \mathrm{~V}, 2 \mathrm{~h}$ at $4000 \mathrm{~V}$ and then for 20000 volt hours at $4000 \mathrm{~V}$. Focused strips were equilibrated in $5 \times$ Tris- $\mathrm{HCl}$ glycine gel buffer containing $6 \mathrm{M}$ urea, $2 \%$ SDS, $20 \%$ glycerol, 5mM TBP and $2.5 \%$ acrylamide monomer. Second dimension separation was carried out using precast $10-20 \%$ polyacrylamide gradient gels with a 2-D miniprep well (Bio-Rad) on a Mini- 
PROTEAN 3 electrophoresis cell (Bio-Rad). Electrophoresis was performed using the standard Laemmli buffer system (Laemmli 1970) at a constant current of $5 \mathrm{~mA}$ for $30 \mathrm{~min}$ and then at a constant current of $12 \mathrm{~mA}$ for $1.5 \mathrm{~h}$. Prestained BlueRanger ${ }^{\circledR}$ molecular weight marker mix (Pierce) was used to compare the molecular weight of protein spots. Multiple gels were prepared for the same protein samples from both treatments to ensure consistency of protein profiles on 2-D gels, and isoelectric focusing was carried out simultaneously to minimize experimental variability. The gels were silver stained and scanned.

Nucleotide sequence accession numbers. The DNA sequences of the Renibacterium salmoninarum sortase and sortase substrate ORFs RRSA01227 (Acc. No. EF426 713), RRSA00417 (Acc. No. EF426712), RRSA00636 (Acc. No. EF426714), RRSA01045 (Acc. No. EF426715), RRSA01248 (Acc. No. EF426716), RRSA01787 (Acc. No. EF426717), RRSA 02499 (Acc. No. EF426718), RRSA00949 (Acc. No. EF426719) and RRSA02971 (Acc. No. EF426720) have been deposited in the GenBank database.

\section{RESULTS}

\section{Characterization of Renibacterium salmoninarum sortase and sortase substrates}

The Rs-33209 genome sequence allowed identification of an ORF (RRSA01227, Genbank Acc. No. EF426713) specifying a sortase enzyme. The deduced protein sequence has a calculated molecular weight of 30682.58 Da and a pI of 7.87. As calculated from ClustalW pairwise alignments, the amino acid sequence of the sortase had significant sequence identity to sortase or sortase-like proteins of Arthrobactersp. FB24 (61\%), Brevibacterium linens (39\%), Kineococcus radiotolerans (36\%), Acidothermus cellulolyticus (32\%), Bifidobacterium longum (32\%) and Frankia alni (32\%) (Fig. 1). All putative genes in Rs-33209 (3515 total open reading frames) were compared to the 6 sortase subfamily models of Comfort \& Clubb (2004). The only significant result was ORF RRSA01227 matching to subfamily 5 (score of 220.2 and e-value of 3.1e-66). The amino acid sequence of this sortase protein clustered in a neighborjoining phylogenetic tree with other Class D sortase enzymes (result not shown). The sortase subfamily 5 described in Comfort \& Clubb (2004) is equivalent to the Class D sortase group of Dramsi et al. (2005). Therefore, the Renibacterium salmoninarum sortase gene is designated $s r t D$ based on the latest classification of sortase enzymes (Dramsi et al. 2005).

All amino acid sequences were scanned for the tripartite pattern and cleavage motif of the subfamily 5 sorting signal resulting in 698 matches to the cleavage motif (LAxTG) and 19 matches to the tripartite pattern (results not shown). According to the criteria used, 8 of the putative sortase substrates were true positives with both features (Table 1). Searching the Rs-33209 genome with an HMM built from these putative sortase substrates or by using the MEME/MAST software as outlined by Boekhorst et al. (2005) failed to yield any additional novel matches (results not shown).

Specific primers were designed to PCR-amplify these gene sequences from the bacteria. All the genes were transcribed in the bacteria as observed by RTPCR (data not shown).

\section{Use of vinyl sulfone sortase inhibitors to inhibit the ability of bacteria to bind Chinook salmon fibronectin}

Many of the sortase substrates studied to date are MSCRAMs. This group of bacterial proteins often includes proteins involved in adherence to eukaryotic matrix proteins such as fibronectin. To investigate the ability of Renibacterium salmoninarum to bind fibronectin (a common ligand of bacterial MSCRAMs), we optimized and used a salmon fibronectin ELISA. Fibronectin protein was purified from Chinook salmon muscle tissue by gelatin sepharose affinity chromatography; the purity of the protein was determined by observing a single high molecular weight protein band on SDS-PAGE. Initial optimization of the fibronectin ELISA was performed using PVS (Frankel et al. 2004). By titrating different concentrations of PVS and fibronectin, it was found that maximum inhibition of fibronectin binding was achieved at doses of $10 \mathrm{mM}$ PVS and $10 \mu \mathrm{g} \mathrm{ml} \mathrm{m}^{-1}$ fibronectin (Fig. 2A). Fibronectin binding ability was significantly reduced $(75.8 \%)$ in bacteria treated with PVS (Fig. 2B) in comparison with controls. The fibronectin ELISA was used to screen 5 other vinyl sulfone drugs at $10 \mathrm{mM}$ doses for their ability to inhibit fibronectin binding and, thus, to indirectly assess their ability to inhibit sortase activity. The reduction in fibronectin binding abilities of methyl vinyl sulfone $(17.53 \%)$, ethyl vinyl sulfone $(12.6 \%)$, divinyl sulfone $(8.14 \%)$, phenylsulfonyl ethylene $(3.47 \%)$ and phenyl trans-styryl sulfone $(1.32 \%)$ were significantly lower than that of PVS. Therefore PVS was selected for all other experiments.

\section{Growth of bacteria in SKDM-2 medium containing vinyl sulfone drugs}

Growth of Rs-33209 in SKDM-2 broth medium was screened by measuring the $\mathrm{OD}_{525}$ of the broth culture 
R. salmoninarum

Arthrobacter sp. FB24

Brevibacterium Iinens

Kineococcus radiotolerans

Acidothermus cellulolyticus

Bifidobacterium longum

Frankia alni

R. salmoninarum

Arthrobacter sp. FB24

Brevibacterium linens

Kineococcus radiotolerans

Acidothermus cellulolyticus

Bifidobacterium Iongum

Frankia alni

R. salmoninarum

Arthrobacter sp.FB24

Brevibacterium Iinens

Kineococcus radiotolerans

Acidothermus cellulolyticus

Bifidobacterium longum

Frankia alni

R. salmoninarum

Arthrobacter sp. FB24

Brevibacterium Iinens

Kineococcus radiotolerans

Acidothermus cellulolyticus

Bifidobacterium Iongum

Frankia alni

R. salmoninarum

Arthrobacter sp. FB24

Brevibacterium Iinens

Kineococcus radiotolerans

Acidothermus cellulolyticus

Bifidobacterium longum

Frankia alni

R. salmoninarum

Arthrobacter sp. FB24

Brevibacterium 1 inens

Kineococcus radiotolerans

Acidothermus cellulolyticus

Bifidobacterium longum

Frankia alni

R. salmoninarum

Arthrobacter sp. FB24

Brevibacterium linens

Kineococcus radiotolerans

Acidothermus cellulolyticus

Bifidobacterium longum

Frankia alni

R. salmoninarum

Arthrobacter sp. FB24

Brevibacterium Iinens

Kineococcus radiotolerans

Acidothermus cellulolyticus

Bifidobacterium longum

Frankia alni
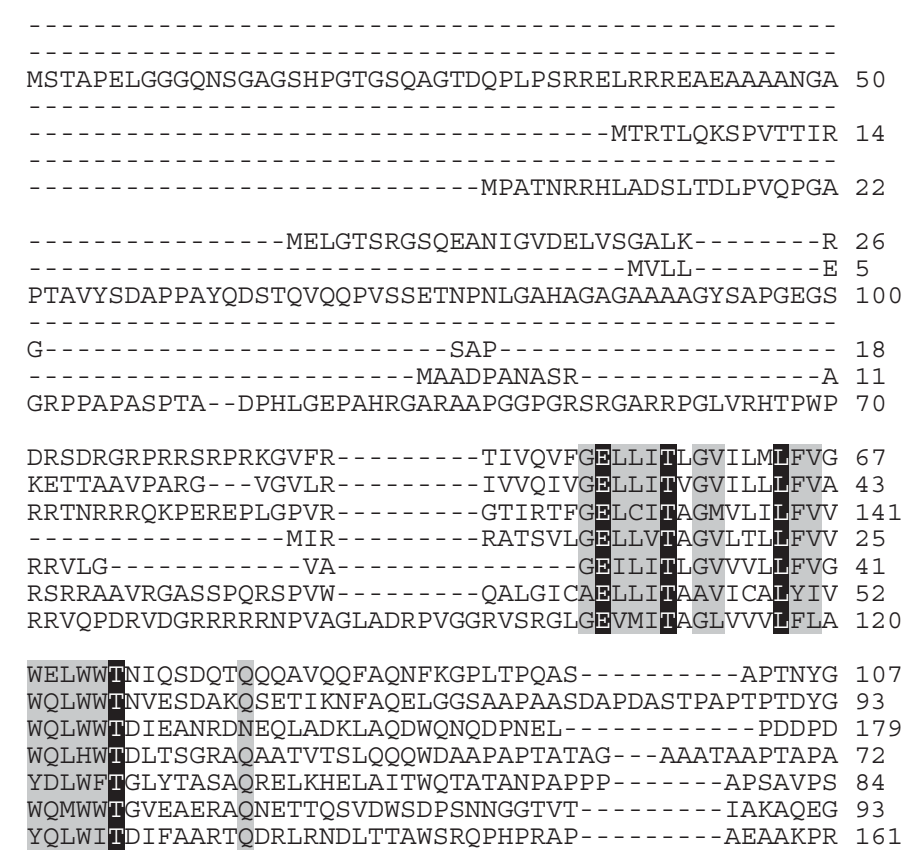

DPVVTKAPDAAGETFGLAYIPRFGADYKPRPLVQGTAQR-ELDTLGLGHH 156 PPRVAEAP - GHGQTIGIMYIPRFGADYT-RPIVQGTSTD-VLDTLGLG-H 139 EP-VVADPVEKNSAFGIFYIPRFGDDYY-RTVAEGVDLEPVLNRMGVG-R 226 TARAVDETPPTGDAFAILHVPRFGEDYA-VPVVEGTGTE--ELKEGIG-H 118 PDGVLPDDVVPGNALALIRIPRLGRHYV-YAIVEGVSTA--DLKKGPG-H 130 DAPVQPKDAKYGDLIAQIYIPRFGSQWH-RNIVEGTTLE-QLNRHGLG-H 140 P - -VVPP - VELGEGVAVLRVPRFGADYA-PVVVEGVSVA--ALRRGPG-H 204

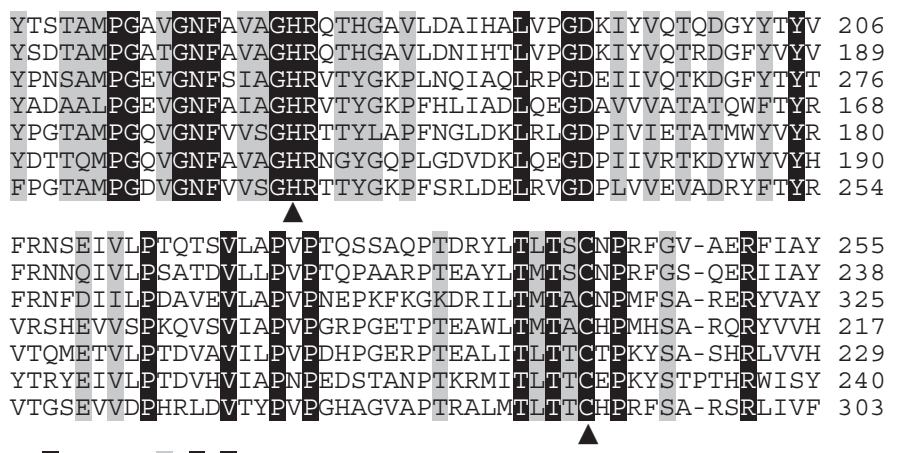

AVTESWOPASAGPPAEIAO_. . - OVQAAAGQG _.

SLLDHWQPASAGPPAEIAA - . - QVAKALGKG $\ldots \ldots \ldots \ldots$

AELTDWTPAGDGAPDNI KDSKAYDKVSKNGGA - . . . . . . . . . . - . - 357

AQLESVQDRSAGPPASLTA - . . . .

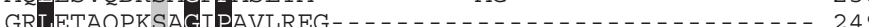

GELAYWAKVSDGVPKELATTDSSGAVMFSTTETPSIASRIGSLDKVVFGA 290

ANLDETTDKSDGPPRALADE $-\ldots \ldots$

Fig. 1. CLUSTAL W alignment of sortase-like protein sequences from different Gram-positive bacteria. Amino acid residues identical in all 7 sequences are shown in white font on a black background. Residues present in at least 5 of the 7 sequences are shown in black font on a grey background. Black arrows indicate the positions of the probable active site cysteine and the conserved histidine residue. $R .=$ Renibacterium

in order to determine whether PVS treatment may affect growth and viability of the bacteria. The growth of Rs-33209 in SKDM-2 medium containing $10 \mathrm{mM}$ concentration of each of 6 vinyl sulfone drugs was not significantly different from that of normal untreated bacteria, indicating that they do not affect the growth of Rs-33209 (data not shown).

\section{Inhibition of cell adherence, cell invasion and CPE}

The ability of Renibacterium salmoninarum treated with PVS to adhere to a Chinook salmon embryo cell line (CHSE-214) was determined by fluorescence microscopy using a fluorescein-conjugated $R$. salmoninarum specific antibody. Normal Rs-33209 cells adhered strongly to 


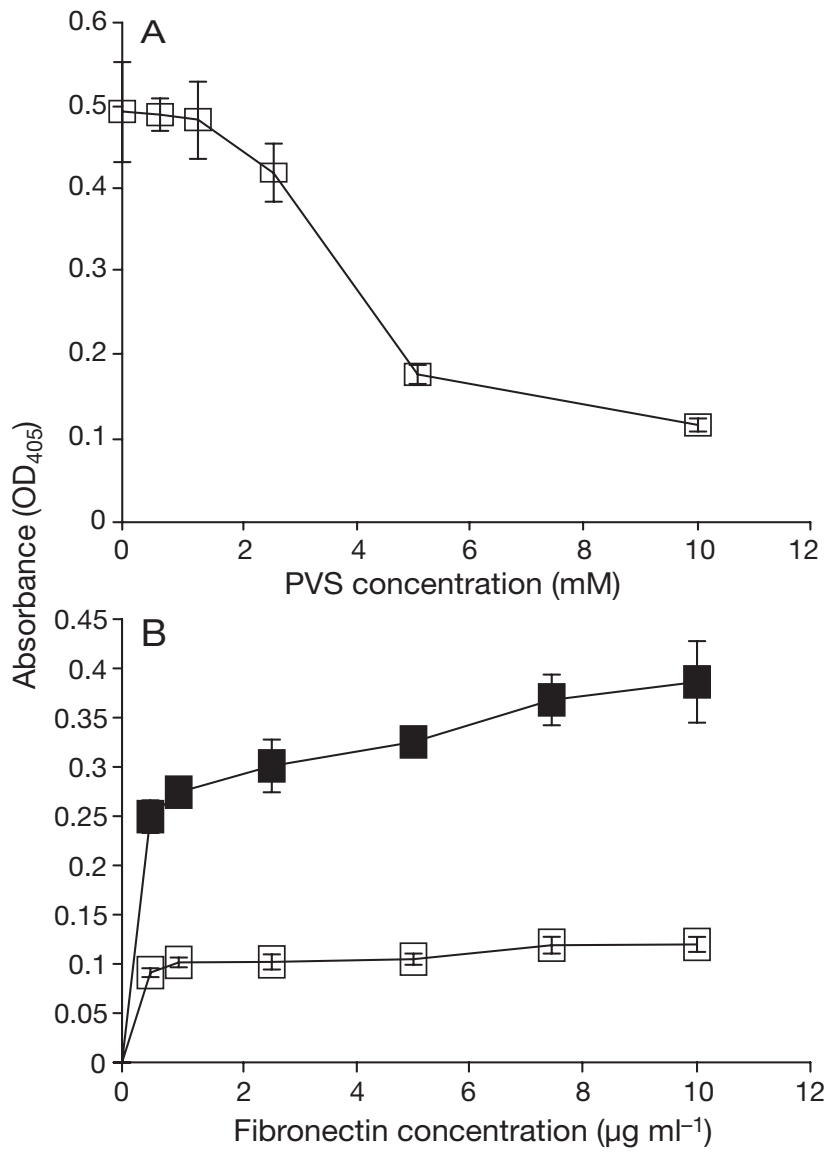

Fig. 2. Chinook salmon fibronectin ELISA curves showing the inhibitory effect of PVS on the fibronectin binding ability of Renibacterium salmoninarum strain Rs-33209. (A) Titration curve of different concentrations of PVS against $10 \mu \mathrm{g} \mathrm{ml}^{-1}$ fibronectin. (B) Comparison of fibronectin binding ability of $10 \mathrm{mM}$ PVS-treated bacteria $(\square)$ with normal untreated bacteria (ם). Results are presented as means \pm SD of triplicate ELISA values

CHSE-214 monolayer (Fig. 3A), whereas the adherence of PVS-treated bacteria was extremely low (Fig. 3B). When the adherence was quantified by the plate count assay, adherence of PVS-treated bacteria was only 17.6\% (SD \pm $4.3 \%$ ) of untreated bacteria (data not shown). A gentamycin protection assay showed that normal Rs-33209 can efficiently invade CHSE-214 cells, and are able to survive and multiply intracellularly (Fig. 4). There was steady growth of the intracellular bacteria over time.

When the CHSE-214 cells were infected with Rs33209 , visible changes in the cell morphology were noted within 3 to $4 \mathrm{~d}$ by microscopic observation of the infected monolayers. The bacteria were found to grow and produce significant cytopathology in these cells in $2 \mathrm{wk}$. The infection on CHSE-214 cells is manifested as extensive CPE on the monolayer, with areas of characteristic rounded cells (Fig. 5C) that gradually spread throughout the monolayer, leading to complete detach- ment of cells from the surface of the well. The PVStreated bacteria with impaired adherence to CHSE-214 cells were not able to grow intracellularly, as observed by both the plate count intracellular growth assay and by microscopic examination. The PVS-treated bacteria did not produce any visible CPE on CHSE-214 cells even after $1 \mathrm{mo}$ (Fig. 5B), and the general appearance of the cell monolayers was not visibly different from that of a normal uninfected cell monolayer (Fig. 5A).

\section{Inhibition of expression of cell wall-bound proteins}

Cell wall-bound proteins from bacteria treated with $10 \mathrm{mM}$ PVS and untreated bacteria were isolated from cell wall components by mutanolysin treatment and differential centrifugation, followed by 2-DE analysis. Two-DE revealed the absence of at least 10 distinct protein spots in cell wall-bound protein preparations from
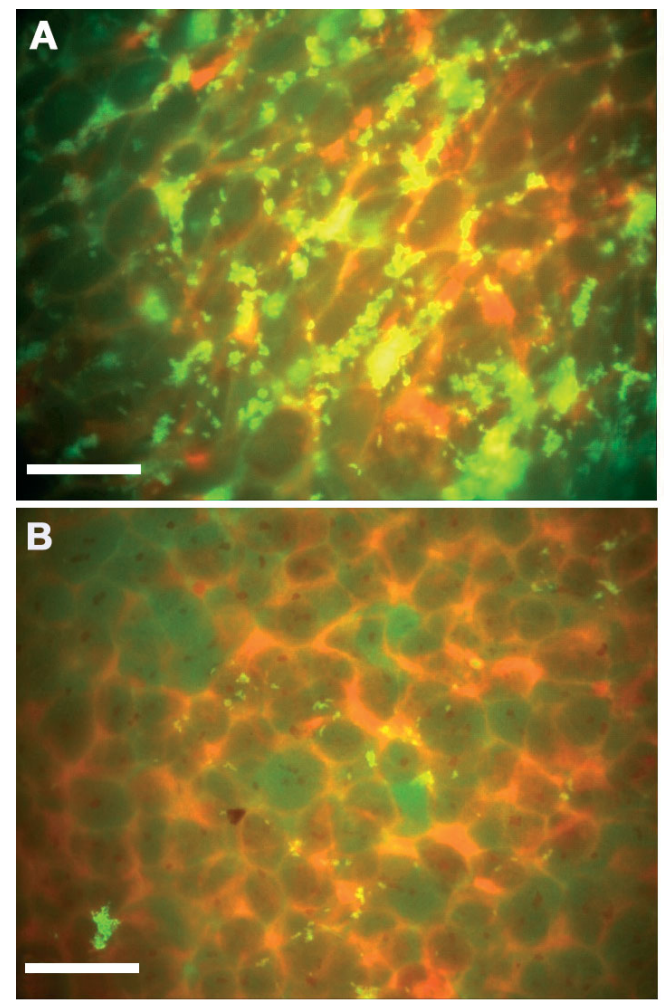

Fig. 3. Adherence of PVS-treated and untreated Rs-33209 to CHSE-214 cell monolayers visualized by immunofluorescence microscopy. After bacterial exposure for $2 \mathrm{~h}$, the cells were washed and treated with fluorescein-conjugated antiRenibacterium salmoninarum goat antibody and counterstained with Evan's blue. (A) CHSE-214 monolayer infected with washed bacteria previously grown in SKDM-2 medium. (B) CHSE-214 monolayer infected with washed bacteria previously grown in SKDM-2 medium containing $10 \mathrm{mM}$ PVS. The apple green fluorescence represents bacteria adhered to cell monolayer in reddish background. Photographs show representative fields of the monolayer. Scale bars $=40 \mu \mathrm{m}$ 

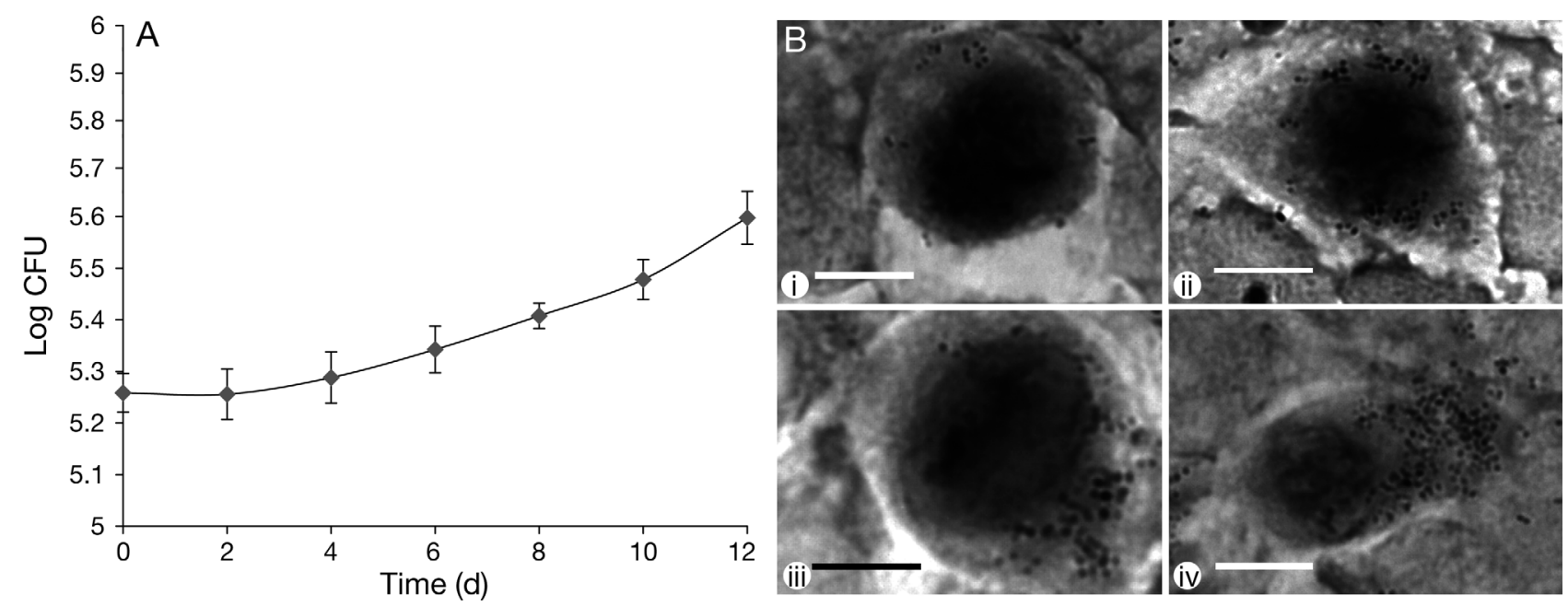

Fig. 4. Intracellular growth of Renibacterium salmoninarum strain Rs-33209 in CHSE-214 cells. (A) CHSE-214 cells were infected and intracellular growth was measured using the gentamycin protection assay as described in 'Materials and methods'. Mean log $\mathrm{CFU} \pm \mathrm{SD}$ estimates from viable plate counts of triplicate samples ( $y$-axis) are plotted for different growth times. (B) Light microscopy of intracellular survival and multiplication of Rs-33209 in CHSE-214 cells over time. CHSE cells were infected by Rs-33209 and extracellular bacteria were killed by using gentamycin (see 'Materials and methods'). Panels show representative Giemsa-stained CHSE-214 cells with bacteria growing inside at (i) $1 \mathrm{~d}$, (ii) $2 \mathrm{~d}$, (iii) $4 \mathrm{~d}$ and (iv) $8 \mathrm{~d}$ after gentamycin treatment. Scale bars $=10 \mu \mathrm{m}$
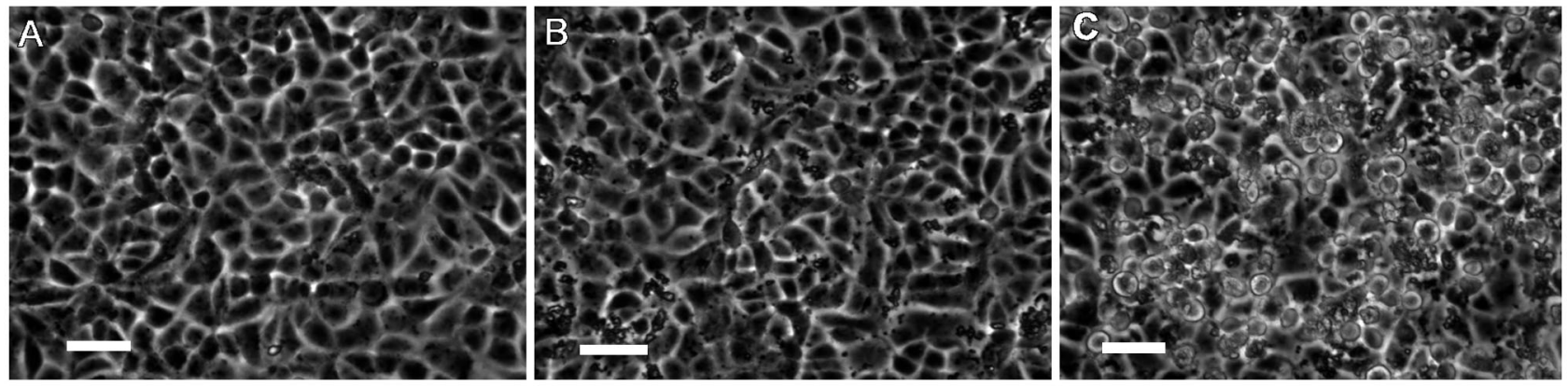

Fig. 5. Cytopathic effect of PVS-treated and untreated Rs-33209 to CHSE-214 cells. (A) Uninfected normal CHSE-214 cells. (B) CHSE-214 cells infected with washed bacteria previously grown in SKDM-2 medium containing 10 mM PVS. (C) CHSE-214 cells infected with washed normal bacteria previously grown in SKDM-2 medium. Scale bars $=50 \mu \mathrm{m}$

PVS-treated bacteria (Fig. 6B) as compared to untreated bacteria (Fig. 6A). Repeated extractions from several groups of PVS-treated and untreated bacteria gave identical results, and the consistency of the 2-DE protein profiles on gels confirmed the differences observed between PVS-treated and untreated bacteria.

\section{Toxicity of PVS to CHSE-214 cells}

PVS at concentrations up to $50 \mathrm{mM}$ was non-toxic to CHSE-214 cells. The cell monolayers grew normally and absence of any CPE, such as visible morphological changes or rounded and detached cells, when observed for up to $2 \mathrm{wk}$ in culture at this concentration of
PVS. At higher doses, precipitation of PVS in the culture medium was observed, making assessment of CPE and morphological observation difficult.

\section{DISCUSSION}

As antibiotics are becoming increasingly inefficient in treating bacterial infections because of the emergence of antibiotic resistant bacteria, alternative therapeutic strategies aimed at the disruption of bacterial virulence are gaining importance in current antibacterial drug development programs. Our finding that PVS, a known sortase inhibitor, dramatically reduces the ability of Renibacterium salmoninarum to adhere, 

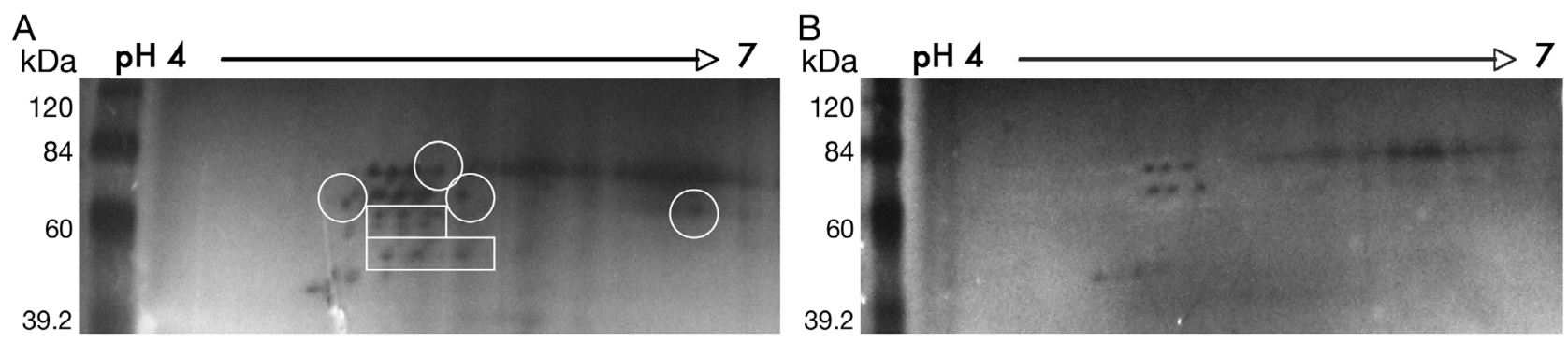

Fig. 6. Two-dimensional gel electrophoretic analysis of cell wall-bound proteins of Rs-33209. (A) Cell wall-bound proteins of untreated bacteria grown in SKDM-2 medium. (B) Cell wall-bound proteins of bacteria grown in SKDM-2 medium in the presence of $10 \mathrm{mM}$ PVS. Circled and boxed protein spots are present in the normal untreated bacteria but are absent in the PVS-treated bacteria

invade, and grow intracellularly in fish cells opens up the possibility of using vinyl sulfone drugs as a potential anti-virulence treatment option for managing BKD in salmonid fish.

The presence of a sortase in Renibacterium salmoninarum was unknown until the genome was sequenced. The Rs-33209 sortase most closely resembles the subfamily- 5 or class D of bacterial sortases based on recent classification schemes (Comfort \& Clubb 2004, Dramsi et al. 2005). Subfamily-5 sortases recognize a LAxTG motif. In contrast, most Gram-positive bacteria possess SrtA or subfamily-3 sortases that recognize proteins with CWSmotifs LPxTG[DE] and LPxTGG, respectively. SrtB sortases recognize an altogether different CWS-motif in Staphylococcus aureus (NPQTN), Listeria (NPKSS) and Bacillus (NPKTG, NPKTD and NPQTG), while subfamily-4 sortases process proteins containing LPxTA[ST] motifs. It is interesting that $R$. salmoninarum has a high $\mathrm{G}+\mathrm{C}$ content $(56.3 \%)$, and that high $\mathrm{G}+\mathrm{C}$ Gram-positive bacteria belonging to Actinobacteria $(\mathrm{G}+\mathrm{C}>55 \%$ ) possess subfamily-5 sortase. Presumably these bacteria have replaced SrtA enzymes with subfamily-5 homologs (Comfort \& Clubb 2004).

Bioinformatics analyses identified the presence of 8 ORFs in the Rs-33209 genome specifying potential sortase substrates with some predicted to be cell surface proteinases or adhesins. These proteins may be MSCRAMs or surface virulence determinants, and may play an important role in adhesion and colonization of the host during Renibacterium salmoninarum infection. Out of the 8 sortase substrate ORFs identified, 7 possess the LAxTG sorting signal recognized by subfamily-5 sortases. Interestingly, ORF RRSA00949 has a sorting motif (LPvAG) that does not fall into any of the proposed 5 subfamilies (Comfort \& Clubb 2004). The presence of only one complete sortase gene $(s r t D)$ in the Rs-33209 genome and the variation in amino acids at specific conserved positions in the sorting motifs found in RRSA00949 point to the possible flexibility of $R$. salmoninarum SrtD in recognizing proteins with different sorting signals. Alternatively, this pro- tein may not be a legitimate $R$. salmoninarum SrtD substrate.

Fibronectin is abundant in the eukaryotic extracellular matrix and plasma, and is the ligand for many bacterial surface adhesins (Joh et al. 1999). Earlier findings have shown that the fibronectin binding ability of $s r t A^{-}$mutants of Staphylococcus aureus (Mazmanian et al. 2000) and S. agalactiae (Lalioui et al. 2005) was severely hampered compared to wild type bacteria. We screened 6 vinyl sulfone drugs (by a fibronectin-binding ELISA) for their ability to inhibit the binding of Renibacterium salmoninarum to Chinook salmon fibronectin. While all 6 vinyl sulfones inhibited adherence to some extent, PVS was the most efficient. Similarly, Frankel et al. (2004) have shown that PVS inhibited fibronectin binding of $S$. aureus to an extent comparable to that of an untreated $s r t A^{-}$ mutant strain. Although the treatment of Rs-33209 with PVS prevented its adherence to fibronectin, the treatment did not have any significant effect on bacterial cell viability and growth. Vinyl sulfones are known to irreversibly inactivate sortase enzymes by capturing cysteine nucleophiles in the active site of the enzyme and forming a stable non-functional thioether adduct (Frankel et al. 2004). Based on the fibronectin binding results, we hypothesize that one or more proteins that are involved in adherence of the bacterium to host tissues are substrates for SrtD and are not displayed on the cell surface of Rs-33209 after PVS treatment. The ability of PVS to inhibit $R$. salmoninarum adherence to CHSE-214 cells was further analyzed. When PVStreated bacteria were used to infect CHSE-214 cells in a cell adherence assay, their binding ability was significantly reduced compared to untreated bacteria. $R$. salmoninarum has a significant ability to adhere to CHSE-214 cells and produces CPE within 4 to $5 \mathrm{~d}$ of infection, whereas most of the PVS-treated bacteria could not adhere to CHSE-214 cells. PVS-treated bacteria were found floating in the culture medium and were easily removed during the washing steps. Further evidence for the difference in adherence of PVS- 
treated and untreated bacteria came from immunofluorescence microscopy of infected monolayers. The fluorescein-conjugated anti-R.salmoninarum antibody detected very few bacteria adhering to CHSE-214 monolayers infected with Rs-33209 previously grown in the presence of PVS. Taken together, these data strongly suggests that PVS is inhibitory to the Rs-33209 SrtD sortase, which results in the disruption of translocation and surface display of many MSCRAMs or other sortase substrates on the bacterial surface. Unequivocal proof of this hypothesis will require construction and characterization of R. salmoninarum mutants lacking $s r t D$.

Mere physical contact between the bacteria and CHSE-214 cells did not result in CPE, indicating the need for specific adherence of the bacteria to CHSE214 cells to produce CPE. The observation that the PVS-treated bacteria did not produce any CPE even after 1 mo of infection suggests that important sortase-mediated surface proteins involved in the virulence of the bacteria were disrupted by the PVS treatment. This finding also supports an earlier study demonstrating that extracellular products (ECP) of Renibacterium salmoninarum did not possess hemolytic or cytotoxic activity, and the injection of ECP did not result in toxicity to fish (Bandín et al. 1991). Conversely these enzyme activities, possibly located on the bacterial cell surface (Bandín et al. 1991, Grayson et al. 1995), are expressed only during intracellular growth (McIntosh et al. 1997). The combination of these prior studies and our current findings strongly suggests a specific requirement of $R$. salmoninarum to adhere to fish cells as a prerequisite for establishing infection. Yet another possibility is the presence of toxin secretion mechanisms similar to the contact-dependent type III secretion systems (TTSS) found in Gram-negative bacteria. In fact, genome sequencing has identified a TTSS in at least one Gram-positive bacterium (Symbiobacterium thermophilum, Ueda et al. 2004). However, a search of the Rs-33209 draft genome did not identify any gene sequences involved in TTSS. The fact that the sortase substrates identified by the bioinformatics approach in this study include 2 adhesin homologs, a surface anchor peptidase, a hydrolase, a sialidase and an acid phosphatase suggests that some of these proteins are involved in the adherence of $R$. salmoninarum to CHSE-214 cells.

It is not surprising that impairment of Renibacterium salmoninarum adherence results in a failure to invade and multiply inside CHSE-214 cells. Although the ability of $R$. salmoninarum to invade phagocytic as well as epithelial and fibroblast cells of fish has been documented (Bandín et al. 1993, Gutenberger et al. 1997, McIntosh et al. 1997), this is the first conclusive demonstration that $R$. salmoninarum replicates intracellularly after invasion. Intracellular survival is an efficient strategy exploited by many pathogenic bacteria to evade host immune responses and/or to allow the bacteria to spread to adjacent tissues from a primary site of colonization. The chronic nature of BKD (Fryer \& Lannan 1993), along with the ability of $R$. salmoninarum to survive intracellularly points to a similar evasion strategy. Intracellular survival likely protects $R$. salmoninarum from exposure to antibiotics such as erythromycin, a probable contributing factor in the reemergence of $R$. salmoninarum after cessation of treatment. Microscopic observation of intracellular bacteria shows that the multiplication of the bacteria inside CHSE-214 cells over time results in lysis of host cells and ultimate release of the bacteria into the extracellular medium (Fig. 4Biv), leading to invasion of adjacent cells and further spread of the infection. Hence, it is possible that bacteria freshly released from fish cells several days after erythromycin treatment are exposed to sub-clinical concentrations of the antibiotic leading to induced macrolide drug resistance. Therefore, intracellular survival combined with the exposure to sub-clinical doses of antibiotic and the consequent induced drug resistance results in macrolide resistant $R$. salmoninarum, partially explaining the chronic nature of BKD in treated salmon populations.

Results from PCR and RT-PCR analyses confirmed that the $s r t D$ and genes specifying 8 probable sortase substrates are transcribed in Rs-33209. This prompted further investigation of the cell surface protein translocation in Renibacterium salmoninarum. A comparative proteomic analysis using 2-DE of cell wall-bound proteins from PVS-treated and untreated bacteria revealed the absence of at least 10 protein spots in the PVS-treated bacteria. This result is additional strong evidence that PVS treatment inhibits $R$. salmoninarum SrtD activity, preventing the translocation and anchoring of these proteins to the cell wall. However, confirmation that these proteins are the same sortase substrates identified by bioinformatics analysis will require characterization using mass spectrometric analysis. Research is underway to characterize each of these proteins and determine their roles in hostpathogen interactions.

Our observation that PVS-treated Rs-33209 are incapable of invading and multiplying inside CHSE214 cells points to the potential use of the drug to specifically prevent the invasion and intracellular growth of Renibacterium salmoninarum in vivo. PVS appears to only affect bacterial surface protein expression and presumably virulence, and therefore is a good example of an anti-infective class of antimicrobial agents (Aberg \& Almqvist 2007, Lee et al. 
2003). Since inhibition of growth or death of the pathogen is not required for drug effectiveness, it is unlikely that PVS-treated $R$. salmoninarum will develop resistance to the drug. This study also showed PVS is non-toxic to CHSE-214 cells at concentrations 5 times that needed to show almost complete inhibition of adherence of the bacteria to fish cells. Investigations are underway to determine the toxicity and pharmacokinetics of PVS and its ability to reduce or eliminate $R$. salmoninarum infection and clinical BKD in experimentally-infected salmonid fish. We anticipate that reduction of virulence of $R$. salmoninarum using small molecule drugs like vinyl sulfones will form an efficient antivirulence strategy and an alternative to antibiotics in controlling BKD. Further experiments are being conducted to generate srtD deletion mutants to confirm the involvement of SrtD in $R$. salmoninarum virulence.

Acknowledgements. We thank S. Miller, Department of Microbiology, University of Washington for allowing use of IEF equipment in his laboratory. We also thank W. Dickhoff, S. Lory, and L. Rhodes for critically reading the manuscript and offering helpful suggestions. This research was supported by a NSF/USDA-CSREES Microbial Genome Grant (WNR-2004-00585) (www.nwfsc.noaa.gov/rs-genome) and from the NOAA FCRPS Biological Opinion Implementation Project. Additional funding was provided by the NOAA Fisheries Service.

\section{LITERATURE CITED}

Aberg V, Almqvist F (2007) Pilicides - small molecules targeting bacterial virulence. Org Biomol Chem 5:1827-1834

Bandín I, Santos Y, Bruno DW, Raynard RS, Toranzo AE, Barja JL (1991) Lack of biological activities in the extracellular products of Renibacterium salmoninarum. Can J Fish Aquat Sci 48:421-425

Bandín I, Ellis AE, Barja JL, Secombes CJ (1993) Interaction between rainbow trout macrophages and Renibacterium salmoninarum in vitro. Fish Shellfish Immunol 3:25-33

Bierne H, Mazmanian SK, Trost M, Pucciarelli MG and others (2002) Inactivation of the srtA gene in Listeria monocytogenes inhibits anchoring of surface proteins and affects virulence. Mol Microbiol 43:869-881

Boekhorst J, de Been MWHJ, Kleerebezem M, Siezen RJ (2005) Genome-wide detection and analysis of cell wallbound proteins with LPxTG-like sorting motifs. J Bacteriol 187:4928-4934

Bolken TC, Franke CA, Jones KF, Zeller GO, Jones CH, Dutton EK, Hruby DE (2001) Inactivation of the srtA gene in Streptococcus gordonii inhibits cell wall anchoring of surface proteins and decreases in vitro and in vivo adhesion. Infect Immun 69:75-80

Bruno DW, Munro ALS (1986) Observations on Renibacterium salmoninarum and the salmonid egg. Dis Aquat Org 1:83-87

Cabello FC (2006) Heavy use of prophylactic antibiotics in aquaculture: a growing problem for human and animal health and for the environment. Environ Microbiol 8: $1137-1144$
Comfort D, Clubb RT (2004) A comparative genome analysis identifies distinct sorting pathways in Gram-positive bacteria. Infect Immun 72:2710-2722

de Castro E, Sigrist C, Gattiker A, Bulliard V and others (2006) ScanProsite: detection of PROSITE signature matches and ProRule-associated functional and structural residues in proteins. Nucleic Acids Res 34(Web Server issue):W362-W365. doi:10.1093/nar/gkl124

Dramsi S, Trieu-Cuot P, Bierne H (2005) Sorting sortases: a nomenclature proposal for the various sortases of Grampositive bacteria. Res Microbiol 156:289-297

Eddy SR (1998) Profile hidden Markov models. Bioinformatics 14:755-763

Evelyn TPT (1977) An improved growth medium for the kidney disease bacterium and some notes on using the medium. Bull Off Int Epizoot 87:511-513

Evelyn TPT, Prosperi-Porta L, Ketcheson, JE (1984) Further evidence for the presence of Renibacterium salmoninarum in salmonid eggs and for the failure of providone-iodine to reduce intra-ovum infection in water-hardened eggs. J Fish Dis 7:173-182

Fairgrieve WT, Masada CL, McAuley WC, Peterson ME, Myers MS, Strom MS (2005) Accumulation and clearance of orally administered erythromycin and its derivative, azithromycin, in juvenile fall Chinook salmon Oncorhynchus tshawytscha. Dis Aquat Org 64:99-106

Fairgrieve WT, Masada CL, Peterson ME, McAuley WC, McDowell GC, Strom MS (2006) Concentrations of erythromycin and azithromycin in mature Chinook salmon Oncorhynchus tshawytscha after intraperitoneal injection, and in their progeny. Dis Aquat Org 68:227-234

Foster TJ, McDevitt D (1994) Surface-associated proteins of Staphylococcus aureus: their possible roles in virulence. FEMS Microbiol Lett 118:199-205

Frankel BA, Bentley M, Kruger RG, McCafferty DG (2004) Vinyl sulfones: inhibitors of SrtA, a transpeptidase required for cell wall protein anchoring and virulence in Staphylococcus aureus. J Am Chem Soc 126:3404-3405

Fryer JL, Lannan CN (1993) The history and current status of Renibacterium salmoninarum, the causative agent of bacterial kidney disease in Pacific salmon. Fish Res 17:15-33

Fryer JL, Sanders JE (1981) Bacterial kidney disease of salmonid fish. Ann Rev Microbiol 35:273-98

Garandeau C, Reglier-Poupet H, Dubail I, Beretti JL, Berche P, Charbit A (2002) The sortase SrtA of Listeria monocytogenes is involved in processing of internalin and in virulence. Infect Immun 70:1382-1390

Grayson TH, Evenden AJ, Gilpin ML, Martin KL, Munn CB (1995) A gene from Renibacterium salmoninarum encoding a product, which shows homology to bacterial zincmetalloproteases. Microbiology 141:1331-41

Gutenberger SK, Duimstra RJ, Rohovec JS, Fryer JL (1997) Intracellular survival of Renibacterium salmoninarum in trout mononuclear phagocytes. Dis Aquat Org 28:93-106

Hanzlik RP, Thompson SA (1984) Vinylogous amino acid esters: a new class of inactivators for thiol proteases. J Med Chem 27:711-712

Joh D, Wann ER, Kreikemeyer B, Speziale P, Höök M (1999) Role of fibronectin-binding MSCRAMs in bacterial adherence and entry into mammalian cells. Matrix Biol 18: 211-223

Jonsson IM, Mazmanian SK, Schneewind O, Verdrengh M, Bremell T, Tarkowski A (2002) On the role of Staphylococcus aureus sortase and sortase-catalyzed surface protein anchoring in murine septic arthritis. J Infect Dis 185: 1417-1424

Katoh K, Kuma K, Toh H, Miyata T (2005) MAFFT version 5: 
improvement in accuracy of multiple sequence alignment. Nucleic Acids Res 33:511-518

Kehoe MA (1994) Cell-wall-associated proteins in Grampositive bacteria. In: Ghuysen JM, Hakenbeck R (eds) Bacterial cell wall, Vol 27. Elsevier Science, Amsterdam, p $217-261$

Krogh A, Larsson B, von Heijne G, Sonnhammer ELL (2001) Predicting transmembrane protein topology with a hidden Markov model: application to complete genomes. J Mol Biol 305:567-580

Laemmli UK (1970) Cleavage of structural proteins during the assembly of the head of bacteriophage T4. Nature 227: 680-685

Lalioui L, Pellegrini E, Dramsi S, Baptista M and others (2005) The SrtA sortase of Streptococcus agalactiae is required for cell wall anchoring of proteins containing the LPXTG motif, for adhesion to epithelial cells, and for colonization of the mouse intestine. Infect Immun 73:3342-3350

Lee YM, Almqvist F, Hultgren SJ (2003) Targeting virulence for antimicrobial chemotherapy. Curr Opin Pharm 3: $513-519$

Marraffini LA, DeDent AC, Schneewind O (2006) Sortase and the art of anchoring proteins to the envelope of Grampositive bacteria. Microbiol Mol Biol Rev 70:192-221

Mazmanian SK, Liu G, Jensen ER, Lenoy E, Schneewind O (2000) Staphylococcus aureus sortase mutants defective in the display of surface proteins and in the pathogenesis of animal infections. Proc Natl Acad Sci USA 97: 5510-5515

McIntosh D, Flaño E, Grayson TH, Gilpin ML, Austin B, Villena AJ (1997) Production of putative virulence factors by Renibacterium salmoninarum grown in cell culture. Microbiology 143:3349-3356

Navarre WW, Schneewind O (1999) Surface proteins of Gram-positive bacteria and mechanisms of their targeting to the cell wall envelope. Microbiol Mol Biol Rev 63: $174-229$

Patti JM, Allen BL, McGavin MJ, Hook M (1994) MSCRAMM-mediated adherence of microorganisms to host tissues. Annu Rev Microbiol 48:585-617

Sanders JE, Fryer JL (1980) Renibacterium salmoninarum gen. nov., sp. nov., the causative agent of bacterial kidney disease in salmonid fishes. Int J Syst Bacteriol 30:496-502

Schneewind O, Mihaylova-Petkov D, Model P (1993) Cell wall sorting signals in surface proteins of gram-positive

Editorial responsibility: David Bruno,

Aberdeen, UK bacteria. EMBO J 12:4803-4811

Schneewind O, Fowler A, Faull KF (1995) Structure of the cell wall anchor of surface proteins in Staphylococcus aureus. Science 268:103-106

Sonnhammer ELL, von Heijne G, Krogh A (1998) A hidden Markov model for predicting transmembrane helices in protein sequences. In: Glasgow J, Littlejohn T, Major F, Lathrop R, Sankoff D, Sensen C (eds) Proc 6th Int Conf on Intelligent Systems for Molecular Biology (ISMB 6). AAAI Press, Menlo Park, CA, p 175-182

Stalhammar-Carlemalm M, Stenberg L, Lindahl G (1993) Protein Rib: a novel group B streptococcal cell surface protein that confers protective immunity and is expressed by most strains causing invasive infections. J Exp Med 177: 1593-1603

Ton-That H, Schneewind O (2003) Assembly of pili on the surface of Corynebacterium diphtheriae. Mol Microbiol 50: $1429-1438$

Ton-That H, Marraffini LA, Schneewind O (2004) Protein sorting to the cell wall envelope of Gram-positive bacteria. Biochem Biophy Acta 1694:269-278

Ueda K, Yamashita A, Ishikawa J, Shimada M and others (2004) Genome sequence of Symbiobacterium thermophilum, an uncultivable bacterium that depends on microbial commensalism. Nucleic Acids Res 32:4937-4944

Weiss WJ, Lenoy E, Murphy T, Tardio L and others (2004) Effect of $s r t A$ and $s r t B$ gene expression on the virulence of Staphylococcus aureus in animal models of infection. Antimicrob Agents Chemother 53:480-486

Wolf K, Dunbar CE (1959) Methods of infecting trout with kidney disease and some effects of temperature on experimental infections. US Department of the Interior Fish and Wildlife Service Special Scientific Report Fisheries No. 286

WHO (World Health Organization) (1997) The medical impact of the use of antimicrobials in food animals. Report of a WHO Meeting. WHO/EMC/ZOO/97.4. Berlin, Germany, 13-17 October 1997. WHO, Geneva

Young CL, Chapman GB (1978) Ultrastructural aspects of the causative agent and renal histopathology of bacterial kidney disease in brook trout (Salvelinus fontinalis). J Fish Res Board Can 35:1234-1248

Zink SD, Burns DL (2005) Importance of srtA and srtB for growth of Bacillus anthracis in macrophages. Infect Immun 73:5222-5228

Submitted: May 2, 2007; Accepted: August 5, 2007

Proofs received from author(s): December 7, 2007 